\title{
Troens grund
}

\author{
Af Henning Sørensen
}

Emnet vil her blive beskrevet dels kronologisk (s. 97-111) ved at redegøre for udvalgte perioder, der viser ændringer med hensyn til, hvad troen grunder sig på, dels systematisk (s. 111-123) ved at redegøre for problemstillinger $\mathrm{i}$ forbindelse med et skabelses- og genskabelsesforløb, der viser, hvad grunden er til, at mennesker overhovedet kan tro.

\section{"Skriftens ord «}

Grundtvig kom ud af sin krise ved årsskiftet 1810-11 med den overbevisning, at saligheden kun kunne opnås ved tro på Kristus som formidleren mellem Gud og mennesket og ikke ved mennesket, der ved en opøvelse af fornuften ville nærme sig det guddommelige. Denne tros grund er Guds ord, som det står i bibelen. Men denne tros grund bundet til den luthersk-ortodokse skrifttro bliver i tiden fremover mere og mere problematisk for ham.

Grundtvig må ganske kort tid efter indrømme, at der er steder $\mathrm{i}$ bibelen, som vi ikke kan forstå endnu, men som tiden vil gøre klarere, indtil de ved tidens ende ligger helt klare. Visse dele kan være klarere for en given tid, fordi de netop er bestemt for denne tid, mens andre dele er dunkle, fordi de er bestemt for en anden tid.

I denne afdækning af de dunkle steder i bibelen har fornuften en funktion, selv om den er underkastet troen, for jo "mere Fornuften udvikles og øves i Troens Tjeneste, des mere Forstand faaer den paa de aandelige Ting (VK 1814, s. XXVII). Selv fornuftsarbejde vendt mod bibelen kan tjene troen, idet fornuften bereder "det nye 
Lys, der skal opgaae over Bibelens Sandhed og vise dens Overensstemmelse med Menneskets alvorlige Tanke (Krønikens Gienmo-le, s. 57). Derfor må de kristne ikke afstå fra at beskæftige sig med tidens alvorlige tanker, men lade dem og bibelens klare sandheder møde hinanden og i det møde adskille løgnen fra sandheden.

Allerede i 1814 (En liden Bibelkrønike for Børn og Menigmand, s.99) begynder Grundtvig at differentiere i skriften og giver visse steder fortrin frem for andre. Grundtvig fremhæver fra Det gamle Testamente de steder, der føres som skriftbevis i Det nye Testamente. I Det nye Testamente lægges vægten især på de fire evangelier. Grundtvig ville gerne, at han kunne anse hele bibelen for et ufejlbarligt Guds ord, ja mener, at han kunne gøre det, "hvis jeg ei nødtes til at gøre mig selv og andre Regnskab for min Tros Omfang" (VK 1814, s. XXIX). Men i denne søgen efter at udsondre den kristne tros indhold og dermed troens grund tvinges han ud i en fortløbende differentieringsproces i bibelens skrifter.

Skriftdifferentieringen og fremhævelsen af bestemte ord er et forsøg på at løse det påtrængende skriftproblem. I denne søgen efter at finde det, der i bibelen er kernen og grundlaget for den kristne tro, trækker Grundtvig nogle ord frem, der bedre end andre formår at udtrykke kristendommens hovedsag. Hertil synes Johannesevangeliet at være særligt velegnet, fordi det er det evangelium, der har flest ordret citerede udsagn af Jesu egen mund. Især Johs. 3,16 fremhæves tidligt af Grundtvig. Allerede 3.s.e.påske $1814 \mathrm{er}$ Johs. 3,16 frem for andre ord det "Livsens-Ord, der kan vække Døde» og give "Syndsforladelse for Jesu Skyld og det evige Livs Haab formedelst Troen paa Ham« (BP, s. 184). Men også andre ord tiltrækker sig Grundtvigs opmærksomhed, som f.eks. Matt. 7,21, Luk. 2,10 og Johs. 3,18.

\section{"Ordet lydelig forkynde»}

\section{Opstandelsens håb}

Angående tiden fra 1811 og frem til den mageløse opdagelse (her s. 105) i 1825 er kirkeåret 1822-23 den periode, hvor der i Grundtvigs teologi sker flest nytænkninger, der alle er forudsætninger for og leder frem til opdagelsen i 1825. 
I den tid, hvor Grundtvig ikke havde været præst, 1813-21, havde han produceret forskelligt, bl.a. historisk arbejde. Som tiden skred frem, blev Grundtvig mere og mere modløs, ikke fordi han følte sit arbejde uvæsentligt, men fordi han følte, at det, der var målet for hans arbejde, blev mere og mere uopnåeligt; han kunne ikke længere håbe derpå. Håbet om, at en ny tid ville bryde frem, blev efterhånden dødt, blev til ligegyldighed. Grundtvig følte sig nærmest død, ja "Graven nær« (Fortalen til Nyaars-Morgen, VU, VII, s. 366ff.).

Men midt i denne modløshed blev Grundtvig kaldet til at være præst i Præst $ø$-Skibbinge i 1821. Denne kaldelse tog han som Guds vilje, og den gav ham et "Opstandelsens Haab«, gav ham »Haab og Lyst« til at fuldføre sit arbejde. Da han var færdig med det, skete det, "hvad Mange vist vilde forsvoret, men hvad jeg aldrig havde tvivlet om". Grundtvig fik advent 1822 et "Præste-Kald i HovedStaden« midt i rationalismens højborg, hvorfra "Vantroen bredte sig over Landet" (sst.).

$\mathrm{Nu}$ ville Grundtvig "forkynde Christi Evangelium, som det, der for de mange Millioner var, er for mig, og skal bestandig være en Guds Kraft til Salighed«(sst.).

Men det var ikke kun denne begivenhed, at Grundtvig blev præst, der fødte dette »Opstandelsens Haab«. Men nu, da han var blevet præst, fik han mulighed for at forkynde det, som han havde arbejdet med i den tid, hvor han ikke var præst. Det havde været hans hensigt i denne litterære periode »at afvæbne Kirkens Fiender og vække Nordens Folk af den dybe Sjæle-Søvn paa Afgrundens Bredd“ (sst.), men ingen havde læst hans skrifter; hans håb om at vinde genklang for hans tanker var ikke blevet indfriet. Men nu fik han pludselig lejlighed dertil, og det tændte dette »Opstandelsens Haab» (sst.).

\section{Erfaringen af det lydelige ord}

Grundtvig havde ikke været præst ret længe, før der begynder at komme nytænkninger inden for hans teologi, forkyndelse og kristend omsforståelse. Det vigtigste kommer til udtryk 5. og 6.s.e.påske 1823 , hvor problemet med hensyn til skriften er på vej til at blive løst. Men forinden skal der redegøres for et væsentligt træk ved prædikenen til 2.s.i fasten 1823, nemlig Grundtvigs erfaring af det lydelige ords magt. 
Det håb, som Grundtvig havde, blev bestyrket i hans nye gerning som præst, hvorved han kom til at tale et lydeligt ord for en menighed på et ganske bestemt sted, kirken, og der følte han mere og mere det levende fællesskab. I dette fællesskab blev begrebet erfaring et af de vigtigste for det, der skulle ske siden hen.

I kampen mod rationalisterne kunne Grundtvig nu som præst erfare, at han havde ret, at hans opfattelse af genoprettelsen af det brudte forhold mellem Gud og mennesket var den rigtige. Han havde personlig erfaret, at hans forkyndelse om Kristus som formidleren havde givet hans hjerte fred, og når han havde erfaret denne fred i sit hjerte, så måtte hans forkyndelse være sandhed og de andres løgn:

»Er det nemlig saa, at Troen paa Jesum Christum virkelig skiænker os Sikkerhed om Syndforladelse tilligemed alvorligt Had til Synden, Lyst til at bestride, Kraft til at overvinde den, Frimodighed til at fremtræde for den retfærdige Dommer, barnlig Tillid til ham som vor kærlige Fader, urokkeligt og glædeligt Haab om evigt Liv og Salighed, kort sagt alt det aandelige Gode vi som Syndere maae føle vi fattes og som Mennesker dog inderlig ønske, giver Jesu Troe os dette, da har vi erfaret os dens Sandhed" (2.s.i fasten 1823, s. 11).

Dette kan Grundtvig slutte sig til ud fra modsigelsens grundsætning: "Noget kan ikke baade være og ikke være i samme Mening" (VU, II, s.264). Men denne erfaring er alligevel ikke et sandhedsbevis, som man vil kunne slutte sig til ved fornuften.

For fornuften er denne sandhed en ubegribelighed, "den hele Betragtning " er "et Intet, med mindre den hviler paa Troen og paa Erfaringen om Evangeliets Kraft« (2. s. i fasten 1823, s. 11).

Det håb, som Grundtvig havde fra sine litterære studier, oplivelsen af dette håb, da han blev præst, sammen med de første erfaringer inden for dette præstekald er de væsentligste indfaldsvinkler til gæringsperioden 1822-23.

\section{Det lydelige ord}

5.s.e.påske 1823 skal Grundtvig prædike over en tekst fra Jakobs brev: "Vorder Ordets Giørere og ikke Hørere alene, hvormed I bedrage eder selv; thi en reen og ubesmittet Dyrkelse for Gud og Faderen er denne, at besøge Enker og Faderløse i deres Trængsel«. 
Denne tekst volder Grundtvig store kvaler, hvis han skal fastholde sit hidtidige bibelsyn, da teksten synes at give rationalisterne ret $\mathrm{i}$, at den sande gudsdyrkelse kun kan finde sted ved at efterleve Jesu moralske lære: "Disse Ord, mine Venner, har, som vi veed, i den sidste tid, med nogle faa lignende, udgjort Verdens Bibel i et kort Begreb« (sst., s.1). Hvordan skal Grundtvig tilbagevise rationalisternes lære? Hvis han giver sig til at diskutere med dem om den rette forståelse af dette skriftsted, hvordan kan han så undgå, at han ligesom rationalisterne kommer til at lægge et klerikalt formynderskab over den rette forståelse af skriften? Han må søge andre veje. I denne prædiken nøjes Grundtvig med at afvise Jakob: "...fordi det i Kirken kan og maa være os aldeles ligegyldigt, hvad Jakob har troet og tænkt, da Man i den christne Kirke aldrig fra de ældste Tider af, har vidst, hvem han var, og da han selv hverken kalder sig A postel eller udgiver sin Tale for et Guds ord « (sst., s. 1).

Men sætningen "Vorder Ordets Giørere og ikke Hørere alene» bliver stikordet for Grundtvig til at fremkomme med et nyt syn på det lydelige ord, hørelsen af dette ord og den fortsatte hørelses nødvendighed for troen:

"...lidet oplyste maatte vi være om vi ei forstode at det hvorved

Troen fødes i os er og det hvorved den næres, styrkes og voxer

til at bære Saligheds Frugt« (sst., s. 13).

$\mathrm{Vi}$ har alle modtaget troen ved at høre; troens fødsel skete ved ordets hørelse. Men denne tro skal leve videre ud over det øjeblik, hvor den blev født, og det kan kun ske ved den fortsatte hørelse.

Da Jesus vandrede på jorden, talte han et lydeligt ord til sine apostle, og ved deres røst skulle ordet udgå til verdens ender. Dette ord har vi som et skrevet ord. Men så stiller Grundtvig spørgsmålet: "Hvem annammede Troen, blot ved at læse, hvilket Folk omvendtes ved de tause Skrifter?« Vi har alle i vores »ørste Ungdom hørt Ordet lydeligt forkyndt", men der er "vist Faae iblandt os, som hvis de glemde Ordet fra Barne-Dagene, atter kom det ihu med Tro, før det lydeligt mødte dem som en Herrens Røst fra troende Læber« (sst., s. 14). Det lydelige ord har fået et fortrin frem for læsningen af det skrevne som troens grund:

"Og, hvad vi alle erfare, saamange som troe, det er, at vel baade kan og skal vi oplyses, og befæstes i Sandheden ved at læse de hellige Skrifter, naar det er os mueligt, men sjelden kun 
opbygges vi, røres vi saa inderlig, befæstes vi saa mærkelig ved Læsningen, der blot indvortes er en Hørelse, som naar vi ogsaa udvortes høre det tone fra Med-Christnes Læber« (sst., s. 14). Menneskeordet er ikke kun en lyd: "... men vi erfare giennem Hørelsens Sans ikke alene noget legemligt - Lyden - men ogsaa noget aandeligt - Ordet «(Dannevirke, II, US,III,s.413).

Men så kunne man spørge, om Grundtvig kan undgå, at det $\mathrm{i}$ stedet for ordet selv bliver den rette hørelse af ordet, ved hvilken troen fødes, næres, styrkes og vokser. Dertil svarer han: Det er ikke "Veltalenhed hos Prædikanten« eller »Lyden«, der gør, at vi »dybere« kan »føle Ordets Kraft og Liflighed «(5.s. påske 1823,s.14), men "det er Ordets og Troens forenede Liv i Menneske-Røsten, ja Ordets og Troens Sandhed «, som »bevæger levende vort Hjerte, idet vi høre dem tone fra et Menneske-Bryst som ikke er vores, som, under al anden Forskel, blot ved hans Aand, som dannede os alle, kunde stemmes til at tale saa vi tænke» (sst.,s.15).

Menneskers sprog er skabt til at kunne blive stemt, således at "vi maatte ligesaagierne paataget os Guds Arbeide en af Skaber-Dagene, som en af Timerne i vor Fornyelse efter hans Billed som skabde os" (22.s.e.trin.1823,s.15).

\section{Det guddommelige ufejlbarlige}

Den næste søndag, 6.s.e.påske 1823, udreder Grundtvig så sit nye syn på skriften, hvorledes man skal komme om ved den tekst, han prædikede over forrige søndag.

For det første fastslår han, "at i Guds Ord kan der ingen Modsigelse være«, for det andet har de kristne »i en forunderlig Søvnagtighed og Ubetænksomhed sammenblandet alle Vidnesbyrd om Christo fra Apostlernes Dage, ikke blot Aandens og Apostlernes, men ogsaa Apostlernes og deres Disciplers, og kaldt det altsammen for Guds Ord«. Derfor er det blevet nødvendigt "at skielne klart imellem Guds og Menneskers Ord“ (sst., s.4). Ved ikke at have foretaget denne skelnen er der sket det, at de kristne ved at påberåbe sig, at hele bibelen er et ufejlbarligt Guds ord, har gjort sig skyldige i en selvmodsigelse ved på den ene side at hævde, at Guds ord er ufejlbarligt, og på den anden side at måtte tilstå, at der i bibelen er udsagn, der strider mod hinanden. 
Således kom Grundtvig på dette tidspunkt frem til, at det urokkelige og ufejlbarlige Guds ord i bibelen er de ordret citerede udsagn af Jesus selv, som apostlene som sandfærdige mænd ved Ånden har vidnet, og så er resten apostlenes vidnesbyrd, og så bliver "deres Vidnesbyrd...lige troværdigt, om end deres Udtryk lyder forskelligt, om for Ex. den Ene talede om to den Anden om tre Kvinder, som kom først til Graven Paaske-Morgen«; det svækker ikke »deres Vidnesbyrds Troværdighed «. Det, der derimod er kriteriet for vidnesbyrdenes troværdighed, er, om de vidner, at "Jesus for deres Øine ved et Ord gav Blinde Synet, Døve Hørelsen, og opvakte de Døde, og især, at han var død og blev levende igien, efter sit Ord, til Beviis paa, han var Guds Søn, og fremviste sig aabenbarlig for sine Discipler« (sst.,s.11).

\section{Johs. 3,16's uafhangighed af skriften}

Det nye syn, Grundtvig 5.s.e. påske 1823 fik på det lydelige ord, får også konsekvenser for de bestræbelser, Grundtvig havde gjort for at konkretisere et troens ord. Disse bestemte ord har nu ikke længere deres forrang, fordi de er ordret citerede udsagn af Jesu egen mund, og fordi de bedre end andre udtrykker kristendommens hovedsag. Men Grundtvig ser nu, at disse ord, lige fra apostlene hørte dem af Jesu egen mund, til de nu lydeligt bliver forkyndt i den nuværende menighed, har været de ord, enhver kristen forkyndelse har måttet udgå fra.

2.pinsedag 1823 udreder Grundtvig det med hensyn til Johs. 3,16. Disse ord var "Sjælen og Livet i hele Mesterens Lærdom", og skal ligeledes være det $\mathrm{i}$ alle hans disciples og i vores. Men så kommer det nye: selv om bibelen på en eller anden måde skulle blive tilintetgjort, f.eks. skulle blive brændt, så ville det ord alligevel blive tilbage, fordi det har lydt i forkyndelsen igennem alle tider. Det vil vandre fra slægt til slægt fra mund til mund. Grundtvig vover altså at give et ord fra bibelen den autoritet at være et Guds ord, selv om det ikke kunne læses i Bibelen. I denne prædiken kan man begynde at fornemme troens ord og ane en lighed $i$ argumentationen svarende til den, han senere fører for trosbekendelsen, fordi han i menigheden tillægger Johs. 3,16 den samme magt og stilling, som han senere tillægger den apostolske trosbekendelse. 


\section{Bekendelsen}

"Der hører hverken Lærdom eller Indsigt eller Heltemod til at være sin Tro bekiendt" (2.s.i advent 1823, s.8). Men det at være sin tro bekendt eller at bekende troen er ikke kun at ville vedstå overfor andre, at man har denne tro. Det er mere et spørgsmål om, at troen vil fortælles og bekendes. Grunden til, at Johs. 3,16 vil vandre fra mund til mund, er ikke, at dette Guds ord har givet en særlig indsigt, som man så vil fortælle til andre. Men hvis dette ord er modtaget - hvis dette ord har bevæget hjertet, så dette ord er blevet troens grund, så ligger det i troen på denne grund, at den vil bekendes. »Bekendelsen følger aldeles nødvendig af Troen, som Apostelen siger: vi troede, derfor talede vi“ (sst.,s.8).

Da troen er tro på en bestemt herre, så må bekendelsen være "almindelig og eenstemmig". Bekendelsen må "være fælles for alle ...med een Mund" (sst.,s.8).

Ud fra Luk. 2,17 påpeger Grundtvig juledag 1823, at hyrderne på marken måtte fortælle det glædelige budskab videre til andre, det glædelige budskab, som englene fortalte dem, at der var født dem en frelser (Luk. 2,10). Det er denne første bekendelse af dette budskab, vi hører i dag. Den bekendelse har vandret og vil vandre fra troende til troende:

"Saalænge, der er Spor og Levning af denne de Christnes glædelige Tro paa Jorden, saalænge maa der og nødvendig høres Gienlyd af Engle-Røsten« (sst., s.2).

\section{Kirken}

Så længe Grundtvig anser skriften for troens grund og kilde, sålænge er der ikke plads til en kirke, $i$ hvilken der gives et vidnesbyrd til salighed, da kirkens formidling af nåden vil være afhængig af den måde, på hvilken prædikanten udlægger skriften. Kirken kan da allerhøjest være, som han siger 2.juledag 1822, en samling af dem, som "den levende og selvstændige Aand...kalder og forsamler, oplyser og helliggiør« (s.9, jf. Confessio Augustana). Kirken er altså kun en samling af troende kristne.

Men 17.s.e.trin.1823 er kirken det sted, hvor "det mageløse Engle-Budskab « lyder. Nu er det Ånden, der stemmer budskabsbringerne til at tale, så det er "Propheter, Apostler og Sønnen selv« 
(s.2), der taler. Ånden er ikke længere den enkeltes personlige ejendom uafhængig af kirken, men i kirken er og virker Ånden. Det er ikke længere den enkelte prædikants egen forkyndelse, der er gerningen i kirken. »Embedsgierningen er ikke vores, men den HelligAands, der ved Guds Ord paa vore Læber sammenkalder, oplyser, helliggiør og i Troen opholder, i Kiærlighed opelsker vor Herres Jesu Christi Menighed“ (22.s.e.trin 1823, s.4).

\section{$»$ Troens ord $"$}

Normalt plejer man at fastsætte datoen for den første gang, Grundtvig redegør for den mageløse opdagelse, til d. 31. juli 1825 , 9.s.e. trin., idet man her knytter sig til Holger Begtrup, der i Grundtvigs kirkelige Syn 1825, K bh. 1901 (s.190) siger, at Grundtvig har gjort opdagelsen i den uge, der leder op til ovennævnte søndag. Det er for så vidt rigtigt, hvis man dermed mener første gang, Grundtvig i en prædiken lader den apostolske trosbekendelse ved dåben være troens grund i modsætning til bibelen.

Men det er at stille problemet for enkelt op.

I prædiken til 9.s.e.trin. 1825 angiver Grundtvig to grunde til den opdagelse, at skrifttroen ikke slår til: 1) de ulærde, enfoldige folks fortvivlede stilling under de skriftlærdes formynderiske eneret på den rette udlægning af skriften, 2) før skriften blev til, var der en levende historisk menighed, der troede på og døbtes i Faderens og Sønnens og Helligåndens navn.

Baggrunden for opdagelsen er bl.a. det, som allerede i fortalen til VK 1814 var problemet: »at giøre mig selv og andre Regnskab for min Tros Omfang" (s.XXIX). Dengang begyndte Grundtvig at løse problemet ved at regne nogle skrifter i bibelen som værende bedre til at redegøre for kristendommens hovedsag end andre. Ved at anse nogle skrifter for at være mindre egnede er det første skridt til opdagelsen i 1825 gjort. Med opdagelsen i 1823 af det levende, lydelige gudsskabte ord i menneskerøsten tager udviklingen for alvor fart, idet dette almenmenneskelige gudsskabte ord nu også får den egenskab at kunne have et kristologisk og soteriologisk indhold. Dette ord er mere egnet til at være det, "hvorved Troen fødes...hvorved den næres, styrkes og voxer til at bære Saligheds 
Frugt« (5.s.e.påske 1823,s.13), end det skrevne. Ligeledes kan nævnes prædiken til 2.s.i fasten og juledag 1823, hvor Grundtvig siger, at bekendelsen af dette budskab følger nødvendigt af troen på dette budskab. Den første kristne bekendelse var hyrdernes på marken. Hyrderne hørte budskabet, troede og bekendte det, og denne bekendelse fandt sted, før bibelen var skrevet.

Selv om man langt tilbage i tiden kan spore træk, der leder frem til opdagelsen, beholdt Grundtvig alligevel Guds ord i skriften som troens grund helt op til 8.s.e.trin.1825:

"Ja, Guds Ords flittige Læsning, under Aarvaagenhed og Bøn,

det er det ufejlbarlige men ogsaa det eneste Middel, hvormed

vi kan vogte os for de falske Propheter" (s. 3).

Grundtvig er stadigvæk bibelteolog, men kun på den defensive front, kun i et forsvar overfor de vantro præster og deres misbrug af skriften.

Grundtvig kæmpede i hele sin tid som præst med to problemstillinger. Den ene var menighedens liv og vækst, og indenfor dette område var de nye tanker i 1823 blevet skabt. Men samtidig skulle han forsvare denne menighed overfor de vantro, og til dette formål måtte han stadigvæk henvise til skriften som troens grund. Men troens grund som henholdsvis bibelen og trosbekendelsen er i henholdsvis prædikenerne op til og i prædikenen på 9.s.e.trin mere et forsvarsværk end en proklamation af nye tanker, for de havde været til stede i lang tid. Men nu tør han bruge »den Trosbekendelse, de Kristne til alle tider, i alle Menigheder har aflagt «, ligemeget "hvad der end staar i Bibelen« (sst.,s.16). Før havde det været sådan, at Kirken var bestemt af skriften, men nu er det kirken, der bestemmer skriften, nu er det kirken og dens tro, der er nødvendig for den rette forståelse af skriften:

"Vi har ikke fundet Kirken i Skriften, men Skriften i Kirken og vi skal ikke staae paa Bogen og lede om Troen, men staae med Troen og læse i Bogen, ikke lægge Bibelen under Bordet, som staaer bedst paa sine egne Ben, men lægge Herrens Bog opladt paa Herrens Bord“ (sst.,s.10).

Kun hvis man grunder troen på noget uden for skriften, kan man forstå skriften, altså hvis man med tro læser i skriften, kan man læse, ellers bliver skriften uforståelig:

"...det første Skridt til at forstaae den hellige Skrift er at blive en troende Christen i Aand og Sandhed, og at hvem der ikke 
fører Troen og den Hellig-Aand med sig til Skriften, kan umuelig finde dem der, men finder kun idel Mørke og Daarskab« (13.s.e.trin.1825,s.2).

Fører man troen med sig til skriften, da vil den vise sig at være en bekræftelse af vores tro og den af vores tro fødte bekendelse og lovsang:

"Vi veed det dog vel, at Folkets Bekiendelse i Dagens Evangelium: Han gjorde det vel Altsammen, de Døve gjorde han hørende og de Maalløse talende, vi veed det dog vel, at det kun var Omkvædet til den store Lovsang som skulde lyde fra alle Folke-Tunger under Himlen, som skulde, efter Prophetens Ord, høres fra Jordens Ender den Retfærdige til Ære (12.s.e. trin.1825,s.3).

\section{»Et guddommeligt Livi Menneske-Naturens Orden«}

\section{De lutherske fadre}

Prædikenerne fra $1832 \mathrm{og}$ fremefter er i almindelighed, men prædiken på Marie Bebudelsesdag 1832 i særdeleshed et opgør, der ikke længere er vendt mod rationalisterne, men mod de lutherske fædre. Det centrale problem for Grundtvig er dåben og dens følger for menneskelivet, dels hvorledes foreningen af det naturlige, mennesket, og det åndelige, den opstandne Kristus, kan finde sted, dels hvilken betydning denne forening får for menneskelivet. Målet for denne forening, "hvad der fulgte af denne Forening for os " (Marie Bebudelsesdag 1832,PF,s.28), er, at det levende ord genføder mennesket til liv. "Livet er Hoved-Sagen" (sst.,s.22).

De lutherske fædre havde ret $\mathrm{i}$, at dåben medfører et helt nyt liv, et liv i Kristus - det kan Grundtvig kun give dem ret i. Men uenigheden opstår med hensyn til, hvad dette nye menneske kommer af. Grundtvig er nemlig kommet frem til et nyt syn på mennesket, nemlig det naturlige menneske, vendt mod en luthersk bodskristen opfattelse af det døbte menneske, hvor dåben er en dødelse og korsfæstelse af det gamle syndige menneske. De lutherske fædre havde anset menneskenaturen for så fordærvet, at dåben var en nyskabelse uden nogen baggrund i det gamle syndige menneske. 
For Grundtvig er dåben også en nyskabelse, men det er det syndige menneske, "der skal virkes paa" (pinsedag 1837,s.3).

Fædrene havde også en anden fejl, der ligeledes forhindrede en genskabelse. De havde ikke forstået, hvad det vil sige, at "Kristus skal fødes og vinde Skikkelse, voxe og blive fuldvoxen i os« (Marie Bebudelsesdag 1832, PF, s.23). De havde ikke forstået, at Kristus virkelig blev undfanget i og født af en moder her på jorden, blev født som et lille barn og voksede ikke bare legemligt, men også åndeligt. For at Jesu liv kan genfødes i mennesket i då ben, må hans liv have været "et guddommeligt Liv i Menneske-Naturens Orden, derfor kan og skal Kristendommen være ligesaa, udspringende ved Troen af Daaben« (Julesøndag 1835, PF, s. 326).

\section{Adskillelsens formål}

Kristus var både Gud og menneske. Det var nødvendigt, at han blev et menneske, levede som et menneske, for at "Herren aandelig" kan gentage "sit Levneds-Løb i enhver Slægt fra Undfangelsen til Himmelfarten“ (Marie Bebudelsesdag 1832, PF, s.22).

Fædrene havde ikke en "levende Tro paa Jesus Kristus som Gud og Mand, Gud med Faderen og Menneske med os, og begge Dele til vor Saliggørelse" (2.s. i advent 1832, PF, s.106). I disse citater har man meget klart udtrykt adskillelsen mellem det guddommelige og det menneskelige og formålet med adskillelsen!

Fædrene havde også omtalt Kristi to naturer, men for dem gik problemet mere på, hvordan disse to naturer "var forenede i Kristo end paa, hvad der fulgte af denne Forening for os, hvorledes ogsaa i os og for os Gud og Menneske skal forbindes, sammensmelte og forenes ved Kristi Aand " (Marie Bebudelsesdag 1832, PF, s.29). Grundtvig taler ikke længere om en sammenblanding, men om en sammenhæng i og et formål med adskillelsen mellem det menneskelige og det guddommelige!

\section{Forbindelsen}

Selv om den kristne anskuelse havde været fordunklet af den lutherske bodspietistiske opfattelse af kristendommen med dens bibelsyn, der havde været presset ned over den, så havde det ikke medført, at Kristi kirke var blevet overvundet. Det døde bogstavs 
sejr over det levende ord var ikke en virkelig sejr, men kun en "Øjenforblindelse, som Kristus ved et Aandepust kunde tilintetgjøre, og vilde det, saa snart vi tillod ham det...

$\mathrm{Nu}$ se vi det klarlig, at Jesus Kristus er i Dag som i Gaar den stærke, der bevogter sit Hus, saa det han haver bliver i Fred; thi hvor man havde Sind til at bevare hans Pagt, Lyst og Tro til at trøstes ved hans Lidelsers Samfund og hans Opstandelses Kraft, der opholdt han midt under Blindheden sin Kirke med Badet, som gjenføder til Guds Rige, og Brødet, som mætter til et evigt Liv« (3.s.i fasten 1833, PF, s. 155).

Når Kristi liv på jorden var et guddommeligt liv i menneskenaturens orden, så kan forbindelsen mellem Kristi og vort liv etableres. Jesus kan være levende tilstede i vort liv, han kan fødes i os. Denne forenings udgangspunkt er Jesu dåb, hvor han i "menneskelig Skikkelse ydmyg nedstige i Vandet og haabefuld opstige deraf" (Fastelavnssøndag 1835,s.6). Ligesom Jesu jordiske liv var i menneskenaturens orden, således var hans dåb det også. I kraft af Jesu dåb kan vi derfor også få del i den velsignelse, der lød ved hans dåb og kan blive til Guds børn ved at blive døbt med hans dåb:

"...og hvem der tænker andensteds end i Daaben at annamme den Aand, Christi annammede, da han var døbt og steg op af Vandet, de maae jo blive skuffede i deres selvgjorte Forventning, thi ligesom han var i denne Verden, saa skal vi være, og Alt hvad der skiænkes os i hans Navn, det skiænkes jo kun $\mathrm{i}$ Kraft af, hvad Faderen skiænkede sin eenbaarne Søn«(sst., s.6).

\section{Menneskets og åbenbaringens forenede røst}

Betingelsen for, at dåben kan have nogen virkning overhovedet, er tro: "...thi Troen er og bliver det eneste Vilkaar Gud har sat for Retfærdiggørelse og Salighed i Jesu Navn« (Fastelavnssøndag 1835,s.9). Dåben er det nådemiddel, hvorved troen kan blive til retfærdiggørelse og salighed:

"Troen er Øiet som vogter paa ham, der mætter med Velsignelse og Daaben er den udstrakte Haand fuld af Velsignelse, som nytter Ingen af dem, der ei agte derpaa, men forfeiler Ingen af dem, som rækker derefter« (sst.,s.10).

Når troen er det eneste vilkår, man kan sætte for dåbens virkning 
og udførelse, for at dåben kan blive til et genfødelsens og genskabelsens bad, så kan man spørge, om troen da ikke bliver den præstation, mennesket skal yde, for at dåben kan få gyldighed? Den tro, mennesket skal have, kan kun anskueliggøres ved at blive verbaliseret, og den kan kun verbaliseres i troens ord. Troens ord er for Grundtvig efter 1832 ikke et efter omstændighederne mere eller mindre nøjagtigt discipelvidnesbyrd overleveret op gennem tiderne i kirken, men er nu "det Troens Ord, han bød os at prædike" (Kr. Himmelfartsdag 1832, PF, s.55), "et Guds Ord, som Herren selv har lagt sine Apostler og dermed sin hele Menighed i Munden" (2.pinsedag 1835, PF, s. 287). Dvs. troens anskueliggørelse, troens ord, er et ord af Herrens mund. Når vi siger og bekender dette ord, så er det ikke en præstation, men en videregivelse af noget overtaget.

Anskueliggørelsen af det overtagne, dvs. troen og bekendelsen af troen, er et nedslag af det guddommeliges åbenbaring i det naturlige menneskelivs ord:

„Og da veed vi jo, at det Troens Ord i vor Mund og i vort Hjærte, det er ingenlunde vort eget, saa naar det udstrømmer levende fra vore Læber, ligesom vi have annammet, da er det ikke os, som tale, men det er Faderens Aand, som taler i os" (Fastelavnssøndag 1832, PF, s.14).

Dette nedslag kan kun knytte til ved det naturlige menneskeliv, da det er en åbenbaring af et guddommeligt liv, som fandt sted i menneskenaturens orden: "...var der intet menneskeligt, hvori Guds-Riget kunde spejle sig, saa var det Rige alle Mennesker ufatteligt" (DCB, s. 468). Nedslaget og tilknytningen betyder så, at mennesket ikke skal yde sin egen frelse, da det guddommelige liv fødes, vokser, lever, dør og opstår i og sammen med det naturlige menneskeliv og kan der sammen med mennesket sige troens ord: "...thi han neddaler til os i vor Daab, og i ham lever, røres og er den kristne Menighed alle Dage, saa naar vi hjærtelig tilegne os Troens og Daabens Ord, da har vi ham blivende i os, da høre vi ham vidne med vor Aand, at vi ere Guds Børn, og da skal Verden, skjønt den hverken ser eller kjender ham, dog fornemme, at der af vor Mund udgaar et Vidnesbyrd om Herren som Gud og Mand, som Verdens Frelser" (6.s.e.påske 1833, PF, s.181).

Dog skal det ikke forstås sådan, at når Ånden sammen med men- 
nesket siger troens ord, så er menneskets rolle i denne bekendelse og anskueliggørelse af troen kun en efterplapring. Men mennesket er ved genskabelsen af det naturlige menneskeliv, der er skabt i Guds billede, i stand til at lære at sige sandheden:

"...thi hvor han er, der klarer al Sandhed sig efterhaanden, fordi han er Sandhedens Aand, og der lærer man efterhaanden at tale menneskelig og dog værdig om Gud, fordi Mennesket er skabt i Guds Billede og efter hans Lignelse" (Pinsesøndag 1833, PF, s.188).

Det guddommeliges åbenbaring i menneskelivet sker for at genskabe menneskelivet til dets oprindelige bestemmelse, at det, der var skabt af støv, skulle udvikle sig til en guddommelig bevidsthed:

"Kristi Levned er et guddommeligt Liv i Menneske-Naturens Orden, derfor kan og skal Kristendommen være ligesaa, udspringende ved Troen af Daaben« (Julesøndag 1835, PF,s.326).

\section{Troens genskabelse}

Den skabelsesbetingede tro

Hvad er Tro i Hjertet inde, Tro, som Hvermand kalder sin, Troen mellem Mand og Kvinde, Mellem dig og Moder din?

Er ei Tro $\mathrm{i}$ alles Munde

Sikkerhed af Hjertens-Grunde!

Alt hvad vi hinanden love

Os er Mundsveir kun og Tant, Hvis at troe vi ei tør vove

Ubeseet, at det er sandt, Thi kun Gud kan vist udfinde Hvad iløn vi har isinde.

Dersom al vor Tro uddøde Spildt blev hvert Oplysnings-Ord 
Livet tomt og Landet øde

Mennesket sin Art afsvor

Visnet var da Stamme-Træet

Mennesket paa Græs med Fæet.

V 158,1-3

Livet kan umuligt leves videre og udvikles, ja det kan ikke leves overhovedet, hvis mennesker ikke tør tage hinandens udsagn for pålydende. Det, at mennesker kan tro det ord, mennesket siger til medmennesket, er det, der adskiller mennesket fra den øvrige skabning.

Kristentro er ligeledes at tage et sagt ord for pålydende, og at det sagte samtidig udretter, hvad det siger:

Christen-Tro er Sikkerheden

Paa Vorherres Jesu Ord

Først om Naaden, saa om Freden

Livets Haab og Trøst paa Jord

Thi Guds-Ordet ingenlunde

Lader sig af Støv udgrunde.

Dersom Christen-Tro uddøde, Al Guds-Kundskab blev til Spot

Haabet tomt og Himlen øde,

Ligegyldigt Ondt og Godt,

Døvt for Sandhed er det Øre,

Som Guds Sandhed ei vil høre!

$$
\text { V 158,4-5 }
$$

Tro på menneskers ord og tro på Guds ord skal ikke kun sammenlignes for at vise parallelliteten, men for at påpege, at hvis mennesker ikke kan tro hinanden, kan mennesket ikke tro på den i ordet åbenbarede Gud: "...var der intet menneskeligt, hvor Guds-Riget kunne spejle sig, saa var det Rige alle Mennesker ufatteligt" (DCB,s.468).

Mennesket blev skabt i Guds billede ved et skabende Guds ord. Denne trossag grunder Grundtvig ikke på 1. Mosebogs ellers så fortræffelige vidnesbyrd derom. Men hvis mennesket ikke var skabt i Guds billede, hvis der ikke var »noget i Mennesket af alt, 
hvad der er i Gud“(DCB,s.442), kunne mennesket ikke have nogen forestilling om Gud og hans egenskaber, og så ville enhver form for guddommelig åbenbaring på forhånd være udelukket. Troen på skabelsens hensigt, "at Mennesket, skabt af Støv i Guds sin Skabers Billede, kunne og skulle udvikle sig til gudommelig Bevidsthed, Klarhed og Herlighed « (DCB, s.445), er ikke opstået efter syndefaldet. Troen var den måde, hvorpå det skabte menneske skulle forholde sig til skabelsens hensigt, der også dengang var en gåde. $\mathrm{Og}$ det er stadigvæk en gåde, der ved ordet vil gøre sig gældende i den synlige verden og ved troen opklares efterhånden. Men ligesom nu, så kunne mennesket ved skabelsen kun forholde sig til denne gåde $\mathrm{i}$ tro.

Denne tro, at Gud skabte al skabning, for at det, der var af støv, skulle udvikle sig fra støvet, er ikke en speciel kristen tro. Den tro har de kristne fælles med den øvrige skabning. Men først når det af støv skabte menneske tror, at det ved syndefaldet faldne menneske ved Kristus kan udvikle sig til en guddommelig bevidsthed, så er det en kristen tro.

\section{Den blinde tro}

Da syndefaldet indtraf, gik troen ikke helt til grunde. Troen blev blind. Troen reduceredes til kun at være en uvirksom rest af det oprindelige, ligesom gudbilledet i øvrigt, gemt og lukket inde i hjertet, der ligeledes ved syndefaldet mistede sin oprindelige bestemmelse, at være det sted, der tiltales af Guds ord. Forbindelsen mellem Gud og mennesket var umuliggjort.

Hjertet kunne kun længes og sukke efter sin oprindelige bestemmelse, nemlig at blive tiltalt og bekende. Når ordet ikke kunne tiltale og dermed give troen liv, så blev troen som sagt blind, den svandt ind til kun at være et dunkelt minde. Den blinde tro var vort eget Hjerte som en Levning af Gudsbilledet i os, ja, som et dunkelt Minde af Menneskets første Opvaagnelse til Liv i Guds Billede og efter hans Lignelse« (21.s.e.trin. 1839, VP, s.20).

\section{Den seende tro}

At troen bliver seende betyder, at der ved troen efterhånden kommer lys over menneskelivets gåde: 
"saa at naar Menneske-Livet i Guds Søns Tro nærmer sig Modenheds-Alderen, da vil de troende ogsaa begynde at se Lys i Herrens Lys og stykkevis opdage den guddommelige Visdom under Narre-Dragten" (DCB,s.444).

Men den blinde tro bliver ikke seende lige pludselig ved genskabelsen. Den udvikles efterhånden til at blive seende. Med dåben er fuldendelsen ikke allerede indtruffet, men den døbte får med dåben som udgangspunkt mulighed for at leve livet mod fuldkommelsen. Den dåb, vi døbes med, Jesu dåb, var også kun begyndelsen til fuldendelsen, himmelfarten:

Kun til spæde Børn i Aanden

Vi gienfødes i vor Daab,

Og i os kun efterhaanden

Voxer Herlighedens Haab,

Kiøbe skal vi derfor Tiden,

Voxe først og kæmpe siden,

Herren selv, med Støvets Kaar

Voxde ti og tyve Aar!

III 283,2

Støv-Hjertets Løndom stor,

Dets Nød i Mørkets Fængsel,

Guds dybe Finger-Spor,

Dets underlige Længsel,

Dets Tro og Lue-Daab,

Dets igienfødte Haab,

Dets Smeltning ved Guds Naade,

Med hele Livets Gaade,

Det kommer for en Dag,

I lydt Mund-Harpeslag!

\section{Korstegnelsen}

Da hjertet ved syndefaldet er blevet stenhårdt, ufølsomt og afvisende overfor Guds ord, må det gøres blødt igen, for at troen kan genskabes. Hjertet har stadig sin blinde tro og den gudbilledlige rest i sig. Denne rest af dets oprindelighed gør, at hjertet længes 
uden at kunne rette længslen mod noget, der kan stille længslen. Hjertet er omgivet af en tåget masse, hvorigennem det ikke kan se, selv om det på grund af den gudbilledlige rest gerne ville. Tågen gør, at hjertet ikke kan se ligheden i ordets gudbilledlighed og sin egen forstenede gudbilledlige rest.

Når barnet føres frem for at blive døbt, slås korsets tegn for dets hjerte. Den døbende præst tegner med Guds Ånds finger korsets tegn på barnets hjerte, hvorved Ånden rører ved hjertet. Hjertet er før genskabelsen behersket af en ulykkelig tilstand, nemlig en ubestemmelig længsel, der ikke kan rettes mod noget forløsende. Men i det øjeblik korsets tegn slås, blødgøres og åbnes hjertet. Ånden fører med sig ordet, som den blinde tro kan ane. Længslen er nu ikke længere ubestemmelig, men målrettet, præget af det, som Guds finger tegner i hjertet. Tågen letter. Den blinde tro vil da finde, at den kan se. Den kan tro ordet, fordi genløsningsordet er af samme art som det ord, ved hvilken troen blev skabt. Ordets lyd i hjertet er ikke en ny lyd, men en genlyd. Genskabelsesordet er ganske vist vanskeligere at tro end skabelsesordet, fordi genskabelsesordet i modsætning til skaberordet virker i det skjulte, og fordi genskabelsesordet har sin omgivende samtid imod sig.

Da korsets tegn blev slået på hjertet, blev hjertet præget med et tegn, der svarer til den gudbilledlige rest i hjertedybet, og hjertet kan derfor ane ligheden mellem det prægede tegn og den gudbilledlige rest og ligheden mellem skaberordet og genløsningsordet, som er Kristus.

\section{Genskabelsens udgangspunkt i det naturlige menneske}

Den tro, som genskabelsesordet skaber i hjertet, er som omtalt ikke en ny tro. Den er en tro, der har sit udgangspunkt i den skabelsesbetingede tro, alle mennesker har til fælles:

Det Ny begynder indenfra,

Skiøndt udenfra det stammer,

Thi Hjertets Tro ved Mundens Ja

Den Hellig-Aand annammer!

III 212,23

Ord, som mennesker kan sige til hinanden, kan skabe liv, trøst, fred 
og glæde. Det, at mennesket i modsætning til den øvrige skabning er i stand til at sige et skabende ord, er det, der afslører gud billedligheden. Når mennesket har erfaret, hvor megen magt der kan være i et ord, der stammer fra et menneske, da vil mennesket også have lettere ved at tro det guddommelige ord. At det guddommelige ord har lighed med genskabelsesordet, er ikke kun en tilskyndelse til at tro det, men det er også en forudsætning. Hvis genskabelsesordet ikke kan spejle sig i menneskelige relationer, er det umuligt for det menneskelige at blive genskabt. Efter at mennesket var skabt af støv, kom det ikke til at opfylde skabelsens hensigt, fordi det ville forholde sig til denne hensigt på anden måde end i tro. I det sande menneskelige må genskabelsesordet tage sit udgangspunkt, for at den genskabte tro kan udvikles til fuldkommen indsigt og forklarelse:

"...derfor har Christendommen i alle Maader en menneskelig Side, der ligesaa lidt maa oversees eller glemmes, som dens Guddommelige, thi vist er det Guddoms-Kraften, som virker Alt, men det er Menneske-Ligheden der skal virkes paa, og det ny Menneske, der skal fødes og opvoxe paa Jorden til et Menneske og skal evindelig være et guddommeligt Menneske«; hvis "den Hellig-Aands Virkninger og det christelige Liv beskrives som Noget, der slet ikke ligner Menneske-Naturen men nedbryder og forstyrrer den...kan vi slet ikke annamme den Hellig-Aand eller leve vor Herres Jesu Christi ligesaa menneskelige som guddommelige Jordeliv, hvortil vi ere kaldte" (pinsedag 1837,s.3.).

\section{Det medfødte og genfødte menneskeliv}

Derfor er det menneskeliv, der genfødes, det ved skabelsen skabte, ved syndefaldet faldne og det ved gudbilledet til genfødslen kvalificerede menneskeliv, "Menneske-Livet i sin allerdunkleste, sin allerfattigste og sin allerureneste Skikkelse dog i Grunden...af samme Art, som Menneske-Livet i sin allerrigeste, allerreneste og allerklareste Skikkelse« (DCB, s.429).

Ensartetheden i menneskeligheden er ikke kun en forudsætning for menneskets genfødsel, men også en forudsætning for, at ordet kunne blive kød anden gang, sandt menneske i den anden Adam, Kristus. Kristi menneskeliv er af samme art som det, der blev kød i 
Adam, hvis ikke, "da udelukte Guddommeligheden Menneskeligheden og Menneskeligheden igjen Guddommeligheden af sig, og der kunde ikke længere være Tale om nogen aandelig og hjærtelig Gjensidighed, Tilbøjelighed og Vexelvirkning«(sst.). At Kristus blev kød, betyder da, at Gudsordet og menneskeordet smeltede sammen. Ligeledes betyder det medfødte menneskelivs genfødsel, at det ved troens ord oplyste menneskeord smelter sammen med Gudsordet.

\section{Forsagelse og syndsforladelse}

Tilspørgslen ved dåben er for Grundtvig et samvittighedsspørgsmål. Samvittigheden er det, at alle mennesker ved, at der er noget, der er sandt og godt, og noget, der er ondt og falskt. Alle mennesker ved også, "at der skal være Trængsel og Angest over hvert Menneskes Sjæl, som giør det Onde« (17.s.e.trin.1845, VP,s.123). Samvittigheden siger ikke, hvad der er sandt, men at der er noget, der er sandt, og noget, der er falskt. Efter syndefaldet kunne mennesket ikke pege på sandheden, men kunne kun på grund af den gudbilledlige rest pege på, at der er forskel på sandhed og løgn.

Genskabelsen og livet i det hele taget finder sted i en verden, der er underlagt og præget af modsætninger mellem liv og død, lys og mørke og sandhed og løgn. Mennesket er før genskabelsen underlagt døden, mørket og løgnen - kort sagt synden. Dåbsbarnet kender ud fra sin samvittighed disse tilstande og kan derfor sige, at det vil forsage dem. Det siger ikke, at det kan, men at det vil, hvis det får hjælp dertil. Ved at korsets tegn er blevet slået på barnets hjerte, er troen blevet seende, derfor ved det, hvor det skal hente hjælpen. Når barnet har svaret ja til at ville vende sig fra djævelen, så kan barnet spørges, om det vil tro, og i bekræftelsen af troen på forsagelsen gives syndernes forladelse til barnet i dåbsordene, der betyder, at barnet nu skal tilhøre en anden herre, end det har gjort hidindtil.

\section{Troens ord som troens grund}

Den apostolske trosbekendelse, troens ord, er et af ordene i den række af ord, der adskiller sig fra andre ord ved at være ord af Jesu egen mund, i hvilke Jesus er nærværende, og i hvilke der er skaben- 
de liv. Disse ord er troens ord, dåbsordene, fredlysningen, Fadervor og nadverordene.

Men troens ord adskiller sig fra de øvrige ord i denne række ved dels at være den oplysning og dels at være det spørgsmål, ved hvilken genfødslen finder og alene kan finde sted. Den døbte ved som skabt, at der er forskel på løgn og sandhed, og at livet kun lykkes ved at vende sig fra løgnen. Når barnet har sagt ja til at ville vende sig fra løgnen, oplyses det ved troens ord om sandheden, Jesus Kristus. Når troens ord har oplyst om sandheden, bliver det samtidig til et spørgsmål, om barnet vil tro på denne sandhed. Troens ord er det eneste ord af Jesu egen mund, der for det ugenfødte barn kan give oplysning om sandheden, og det eneste ord, der kan stilles som spørgsmål.

Fadervor kan for den tvivlende, for den svage tro, være et suk, der modtages af Jesus, og som Jesus vil bede sammen med den, der sukker, således at sukket bliver til bønhørelse. Den sukkende vil da atter blive bekræftet $i$, at han er et Guds barn, og troen vil da atter få nyt liv. Men for det første gælder det kun for den genfødte, og for det andet er det ikke kun Fadervor, der kan bekræfte fader-barnforholdet og give troen nyt liv. Det kan ethvert ord af Jesu egen mund, i hvilket han er nærværende. Det gælder altså for denne række af ord incl. troens ord, at de kun har deres gyldighed, hvis mennesket er genfødt, hvis troen ved troens ord er genskabt i dåben; for "Denne Ordets dybe Hemmelighed maae vi først have fattet i Troen, førend vi kan tale tydelig om Herrens og Frelserens aandelige Narvarelse hos sine Egne alle Dage til Verdens Ende« (1. juledag 1858, VP, s.460f.).

Fadervor er som sagt et ord af Herrens egen mund, ja, Fadervor er netop udtryk for fællesskabet mellem Jesus og den genfødte ved, som Valdemar Leth Ludvigsen viser (her s. 178), at de kan bede sammen og bede for hinanden: "...vi maa bede "Fadervor" paa hans Vegne, ligesom han beder det paa vore Vegne, altsaa i Følelsen af vor Enhed med ham, ved Troen i den Helligaand...men det maa ogsaa være Troens Hemmelighed, at dette Fællesskab indtræder ved Troen « (DCB,s.382).

Fadervor er udtryk for håbet, også selv om dette håb kun er et svagt og spædt suk, der grunder sig på en svag, spæd og næsten uddød og tvivlende tro. Fadervor er et håbsord - ikke et trosord: "...thi, ligesom der maa være et saadant udvortes Guds-Ord 
hos Menigheden, for at vi kan kjende, hvad der i Aandens og Ordets Verden er Vorherres Jesu Kristi eget, saaledes lærer Aanden os snart, at ligesom Menighedens Tros-Bekjendelse efter Herrens Mund er den Kristne Tros uforanderlige og uforbederlige Udtryk, saaledes udtrykker Herrens Bøn, som han selv ved Daaben lægger sin Menighed i Munden, nemlig vort "Fadervor « som Børne-Bønnen i Guds Hus, klarlig alt, hvad det i Daaben gjenfødte Guds-Menneske forlanger og forventer af sin himmelske Fader, udtrykker altsaa det kristelige Haab» (DCB,s.465).

Fadervor er som ovennævnte citat viser et håbsord, "og med Christen-Livets Haab og Kiærlighed stod det sig maadelig, at man vilde pine begge Dele ind i Troes-Begrebet, istedenfor at følge dem fra deres Udspring i Aanden og Troen, lyslevende giennem Daaben og Nadveren, til deres Indløb i Paradis« (Christenhedens Syvstjerne, udg. 1955, s. 42).

Troens ord er troens grund. Hvis Fadervor hævdes at være troens ord, uden der skelnes mellem troens ord som troens grund og troens ord som et ord i rækken af ord af Jesu egen mund, i hvilke han er nærværende, og i hvilke han er virksom og dermed kan bede for den sukkende, gives der frit spillerum for al muligt sværmeri, idet det så tilsløres, på hvilket troen genskabes, og hvilken tro der bliver genskabt.

\section{Den moderlige tro}

Ved troens genskabelse smelter menneskeordet og Gudsordet sammen. Dvs. der bliver et livsfællesskab mellem barnet og Kristus. Kristus fødes i os ved vor genfødsel og lever sit liv i vort liv. Derfor er troen en moder, en åndelig moder til dette liv, der indeholder "Vorherres aandelige, men virkelige og kraftige Nærværelse og ...hans Herlighed, som vi skal see, naar vi kan troe» (16.s.e.trin. 1856,VP,s.389). Denne nærværelse og herlighed manifesterer sig i håbet og kærligheden:

Troen dog en Barne-Moder

Ligner mest, som Hjertet veed, Haabet er vor Kirke-Broder, Systeren er Kiærlighed! 


\section{Kvindehjertets dybe laengsel}

2.s.i fasten 1837 bestemmer Grundtvig kvinden eller rettere kvindehjertet som værende det, der har de bedste egenskaber for at føle sig tiltalt af Guds ord. I hele kristendommens historie har kvinderne indtaget en afgørende rolle, men de to vigtigste kvindebegivenheder er, at Jesus blev født af en kvinde uden nogen mands hjælp, og at det var en kvinde, der kunne forkynde, at Kristus var opstanden, mens mændene ikke ville tro kvindernes vidnesbyrd:

"Marie Magdalene var den Første som saae den Opstandne, saa ligesom Herren fødtes af en Kvinde, saaledes fødte ogsaa Kvinde-Læber det store Evangelium om den Korsfæstede igien Opstandne, medens Apostlerne endnu tvivlede - leve de troende Kvinder. Amen! i Jesu Navn Amen!«(sst. s.8).

Kvindens hjerte har den bekvemhed fremfor mandens, at det bedre kan tiltales af Guds ord og dermed genføde troen. I nedennævnte prædiken bestemmer Grundtvig denne bekvemhed som værende godtroenhed, udmyghed og kærlighed. Denne bekvemhed havde jomfru Maries hjerte, således at hun kunne føle sig tiltalt af ordet og bekende og føde en søn, Jesus Kristus, herlighedens håb:

"Han som randsager Hjerter, fandt hos Kvinden en Bekvemhed til Samfund med Guds Aand, som Manden fattedes, og som altsaa maatte findes i den Godtroenhed, Ydmyghed og Kiærlighed, der hos Kvinden har sit egentlige Sæde og fødte det store Ægteskabs-Løfte paa Jomfru Maries Læber: see, jeg er Herrens Tjeneste-Pige, maa det gaae mig efter dit Ord! Her ligger nemlig Troen paa Guds Ord indesluttet som noget, der fulgde af sig selv, medens Hjertet i dybeste Ydmygelighed udtrykker sin fulde Hengivenhed, ja Overgivelse til Gud, og aabenbarer saaledes hvad Aanden kalder Kvinde-Hjertets skjulte Menneske, som er saare dyrebar for Gud « (sst., s. 6). Fordi jomfru Maries hjerte var godtroende, ydmygt og kærligt, fordi englens ord knyttede til ved noget i Maries hjerte, der kunne føle sig tiltalt af ordet, om at hun skulle føde en søn, så kunne hun tro englens ord og bekende: "see, jeg er Herrens Tjeneste-Pige, maa det gaae mig efter dit Ord «. Denne bekvemhed har kvinden altid haft. Kvinden er for Grundtvig først og fremmest moder til liv, ligesom Eva, den første kvinde, var mor til alt liv. Mandens hjerte 
og dermed hans følelser er i tidens løb blevet undertrykt af forstanden. Derfor lever kvinderne i større overensstemmelse med den sande menneskelighed og kan derfor bedre tiltales af ordet, hvorved kvinden har været bedre til i hjertet at bevare disse egenskaber, der kan genføde, og som er troens egenskaber, der stammer fra skabelsen, er gudsskabte og efter syndefaldet bevaret i den guddommelige rest, kvindehjertets skjulte menneske, $\mathrm{i}$ hjertet $\mathrm{i}$ dvale. Derfor genfødes troen nemmere hos kvinder end hos mænd.

Når Ånden i ordet rører ved hjertet, og hjertet føler sig tiltalt af ordet, så vil troen, der mellem syndefald og genskabelse har været blind, i ordet kunne se ham, der siger: Se, jeg er verdens lys! Når hjertet røres og tiltales af ordet, og når de egenskaber, der er en rest af de forhold, der oprindeligt var mellem skaberen og det skabte, kan få noget at være godtroende, ydmygt og kærligt overfor, da følger troen af sig selv.

\section{Håbet}

For overhovedet at kunne håbe må man tro:

Kun med Tro vi Haabet favne,

Kun med Tro vi knæle ned,

For at finde hvad vi savne

I vor Frelsers Kiærlighed!

Tro og Håb er givet mennesket i skabelsen. For det ved syndefaldet faldne og ugenfødte menneske kan håbet kun give sig udtryk i en ubestemmelig længsel, men for den genfødte genskabes det ved skabelsen givne håb. Håbet fødes af den genskabte moderlige tro:

Da gienfødes Tro saa fage,

I det store Trilling-Navn,

Vender moderlig tilbage,

Med en Gudsøn i sin Favn,

Som skal aldrig smage Døden:

Haabet, Guddoms-Morgenrøden! 
Troen er menneskets måde at forholde sig til den endnu uafklarede menneskegåde på, og den hører derfor hjemme på jorden og vil således være uden funktion i fuldkommenheden, hvor gåden vil være løst. Håbet hører til og svæver mellem fuldkommenheden og ufuldkommenheden, og håbet vil ligesom troen være uden funktion, når håbets genstand, Kristus, er blevet fuldstændig ligedannet med håbet, herlighedens hå b. Håbet er derfor foreløbigheden, troens eskatologiske holdning:

\section{Letvingede Haab!}

Gudbroder! gienfødt i den hellige Daab! For Reiserne mange til Landet bag Hav, For Tidender gode, for Trøsten du gav, Lad saa mig dig takke, at Glæde jeg seer,

Naar Haab er ei meer!

$$
\text { III } 86,10
$$

\section{Karligheden}

Troen grunder på kærlighed. Da troen blev skabt ved skabelsen, blev den skabt ved et ord, der var en kærlighedserklæring. Denne kærlighedserklæring skulle mennesket forholde sig til i tro. Ligeledes er genskabelsesordet, Kristusbarnet det lille, en kærlighedserklæring til den skabning, Gud ønsker skal blive til hans barn.

H jertet kommer lettere til at elske genskabelsesordet, fordi det er en større åbenbaring af faderkærligheden, men genskabelsesordet er vanskeligere at tro end skaberordet, fordi det virker i det skjulte, har sin omgivende samtid imod sig og kun kan ses med "Hjærtets Øjne«, mens skabelsesordet virkede i det åbenbare.

Menneskets tro er tro på kærlighed. Men sålænge mennesket lever i ufuldkommenheden, vil kærligheden ligeledes være ufuldkommen, være en gåde. I fuldkommenheden vil der være fuld klarhed over gåden, gåden vil være løst, kærligheden vil være fuldkommen, og troen og håbet vil være uden funktion.

\section{Tro, håb og karlighed}

Ved dåben får troen mulighed for at blive genskabt, men skal denne tro være forudsætning for, at menneskelivet kan nå sin fuldendelse, 
så kan troen ikke stå alene, men et ord, der har genskabt troen, må også ved troen have genskabt håbet og kærligheden, uden hvis tilstedeværelse troen ikke kan leve, og fuldendelsen ikke kan opnås.

Troen, håbet $\mathrm{og}$ kærligheden udgjorde i skabelsen ved ordet det oprindelige menneskeliv i Guds billede. Hvis det ved syndefaldet faldne menneske skal genskabes, er det da en forudsætning, at der i den gudbilledlige rest findes en levning af det oprindelige menneskeliv $\mathrm{i}$ tro, håb og kærlighed, som ordet kan knytte til ved:

"...at der hos det faldne Menneske kan være, har været og maa, saa længe Gjenfødslen skal være mulig, findes tænkelig og gjørlig i Sandhed, være baade Spor og Levning af Menneskets oprindelige Godhed og Herlighed, som en Skabning i Guds Billede, der veed af Gud og sig selv at sige; og, saa vist som "Tro, Haab og Kjærlighed" udtrykker hele den menneskelige indvortes Billed-Lighed med Gud, saa vist maa der hos det faldne Menneske, som skal kunne oprejses, hos det fortabte Menneske, som skal kunne frelses, og hos det vanartede Menneske, som skal kunne gjenfødes, findes en virkelig Levning af Troen, Haabet og Kjærligheden, som de oprindelig udgjorde og udtrykte Menneske-Livet i Guds Billede« (DBC, s. 455).

Troen, håbet og kærligheden er før genskabelsen de naturlige menneskelige relationer tro, håb og kærlighed, og det bliver de ved med at være også efter genskabelsen. Menneskelivet vil stadigvæk blive fastholdt $\mathrm{i}$ disse relationer, uden hvilke menneskelivet ikke kan leves.

Efter genskabelsen får troen, håbet og kærligheden endnu en funktion, idet de nu peger tilbage og frem. De peger stadigvæk tilbage til tro, håb og kærlighed som menneskelige relationer, og de kan nu ved at troen er blevet seende pege "igennem « syndefaldet og lade ane det oprindelige forhold mellem skaberen og skabningen. Denne genoprettelse, fuldkommenheden, åbnes der mulighed for ved troens genskabelse. 